Trends of innovation of primary education in Europe:

Goals, curriculum, teaching methods, assessment, organization, structure in the educational system, cooperation with municipality, with parents

Norouzi Larsari, Vahid

PhD Student in Education, Department of Pre-primary and Primary Education

Charles University, Prague, Czech Republic (vahid.larsari@gmail.com)

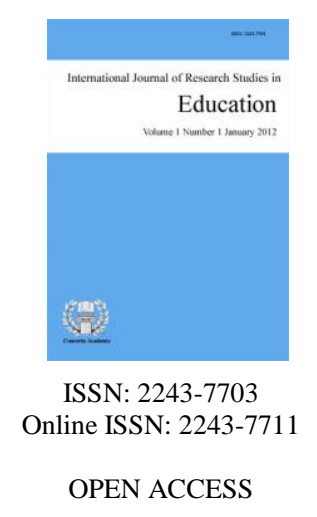

Received: 17 February 2022

Revised: 19 February 2022

Available Online: 25 February 2022 DOI: $10.5861 /$ ijrse.2022.162

\title{
Abstract
}

The present study aims to investigate the new trends of innovation of primary education in Europe and Czech. To this end, the researcher selected six main indicators on new trends of innovation of primary education in Europe and Czech Republic as holistic approach. These 6 indicators include 1) Structure of Educational Systems, 2) New Recent Developments in ICT in the European Primary education, 3) Teaching Methods in Primary Schools (Europe vs Czech Republic), 4) Curriculum Education System, 5) Evaluation and Assessment, and 6) Parent Participation in Primary Education. It is worth noting that the researcher explains the educational context in Europe and Czech for each indicator which constitutes information about the educational context in Europe and Czech.

Keywords: primary education, education system, new recent developments in ICT, evaluation and assessment, curriculum 


\section{Trends of innovation of primary education in Europe: Goals, curriculum, teaching methods, assessment, organization, structure in the educational system, cooperation with municipality, with parents}

\section{Introduction}

Nowadays, primary education is the foremost and basic right of every child. It is the first step in making of the character of child. The role of primary education is to ensure broad based learning of the child. This includes development of social, cognitive, cultural, emotional and physical skills. This education should be delivered keeping information and entertainment hand in hand. On the other hand, primary school should aim at providing rich, stimulating and caring environment in which the child feels happy, safe, secure and confident. Learning at this young age should give birth to creative and enquiring minds. The overall aim of the present paper is to investigate the new trends of innovation of primary education in Europe and Czech. The researcher selected 5 main indicators on new trends of innovation of primary education in Europe and Czech Republic as holistic approach. These indicators constitutes 1) Structure of Educational Systems (Characteristics Of Primary Education Systems in Europe, Three Main Types Of Education Systems In Europe, Structure of the Education System In Czech Republic), 2) New Recent Developments in ICT in the European Primary education (Recent Findings on the Uptake of ICT in Education in European Countries, Digitization of Schools, Assessment and Digital Exams, New Trends of Technology of Primary Schools in Europe and Czech Republic, and ICT in Czech Republic), 3) Teaching Methods in Primary Schools (Europe vs Czech Republic), 4) Curriculum Education System, 5) Evaluation and Assessment, and 6) Parent Participation in Primary Education. It is worth noting that this study explains the educational context in Europe and Czech in each indicator.

The selection criteria of these indicators is done by the working committee of national experts give a full series of information, which draws a picture of quality in European Primary schools (European Commission, 2000). With respect to the commission reports (2000), the presentation of these important indicators help European countries to look outwards rather than inwards so that they can explore their performance in comparison with other countries. In addition, Europe is formed by varieties such as various cultures and languages. These differences are obvious in many dimensions and can also be observed in the structure of the different education systems (Ministers of Education and Cultural Affairs of Germany, 2014). According to the reports of OECD (2019), systematically comparing education indicators across countries give information regarding the state of education to policy makers, educators, students, parents and the public.

\section{Part (1): Structure of the Educational System in Europe and Czech Republic}

\subsection{Characteristics of Primary Education Systems in Europe}

There are almost 209,866 primary schools in the 30 countries surveyed, ranging from 14 in Liechtenstein to 55,329 in France. Many of these primary schools are small and in isolated or rural areas: including, for example 4,285 in France and 1,185 in Finland. Compulsory schooling in the countries covered by STEPS begins between the ages of four to seven. Teacher supply, entry qualifications, conditions of work and salaries vary considerably: for example gross monthly salaries range from $€ 200$ (Romania) to $€ 3,195$ (Denmark) and among the 21 reporting countries the average was $€ 1,630$. Most primary schools are managed, funded and governed by the local municipal councils - and so data tends to be held locally and is not always available. However, even based on fragmented information, a number of core characteristics appear among primary schools in Europe:

Teachers working at primary level are predominantly female. Primary teachers typically stay with one class of children all day. Most primary schools are free of exam pressure compared to secondary level. Children are in 
relatively small schools. A first language, mathematics, science and technology (MST) are the competences most likely to be part of the compulsory primary school curriculum; entrepreneurship is the subject least likely to be taught, but even so appears in the curricula of 12 countries. Digital competence is formally in the curriculum (in different forms) in 22 of the 30 countries. Rethinking the curriculum, pedagogical and subject change (notably language, science and mathematics), and increasing school autonomy are the major reform topics in the countries surveyed. The education priorities most frequently mentioned by policy makers as being those where ICT could make a difference were: those addressing management and administration issues, teacher training, low pupil achievement, and communication and collaboration.

\subsection{Three Main Types of Education Systems in Europe}

In 2019-2020, in the 28-member European Union (EU-28), there are three main types of education systems as regards primary and secondary education: the so-called "single", "common core" and "early tracking" structures. Single-structure systems are characterized by general education programs followed by all students, which are provided in a single institution covering primary and lower secondary education. These systems are found in the North and East of the Union. Common core structures are also characterized by a general education programme followed by all pupils, but unlike the single structure, this is provided in two separate institutions, one for primary and one for lower secondary education. This modality, which is the most common in the Union, is mainly observed in Western and Southern European countries, including France. In the last type of structure, known as 'early tracking', pupils are oriented, from the end of primary education, towards general or vocational education programs of varying content and duration. This structure is found in Germany, Austria, Lithuania, Luxembourg and the Netherlands. Finally, it should be noted that in some Eastern European countries, so-called single and common-core structures coexist. In these countries, pupils' "traditional pathway" is organized in a single structure, but they may decide to move towards parallel structures covering the whole of secondary education. For example, in the Czech Republic, pupils may decide at age 11 to take an examination to enter technical institutions rather than remain in the traditional single-structure pattern until age 15.

\subsection{Structure of the Education System in Czech Republic}

A typical characteristic of the first stage of the transformation was the de-monopolization of state education, facilitating the setting up of private and denominational schools, and stipulating that parents and students should be free in their choice of educational route and school. Another important change has been the restoration of eight-year grammar schools which were a typical component of the education system before the Second World War. The restoration of early selection during compulsory education has been criticized by Czech education policy analysts and OECD experts (OECD, 1996). It has also been the subject of criticism from basic school teachers (Greger \& Walterová, 2007).

The Education System: Czech Republic - The education system in the Czech Republic covers elementary school, secondary school, and post-secondary school (Organization for Economic Co-operation and Development, 2104). According to OECD (2016), the education system is highly remarkably in Czech Republic.

Pre-Primary Education - In Czech Republic, nursery schools (mateřská škola) provide pre-primary education for children usually from 3 to 6 years. Municipalities guarantee places for children from the age of 4 . From the age of 5 , the pre-primary education is compulsory and free of charge. Otherwise, the fees in public and state schools are considerably regulated (OECD, 2016).

Children from 3 to 6 years are entitled to pre-primary education from September following their fourth birthday. Similarly, the compulsory preprimary education lasts from the school year after the child's fifth birthday until the beginning of the compulsory school attendance (OECD, 2016). 
Table 1

Pre-primary education System in Czech Republic

\begin{tabular}{ccc}
\hline Institution & Ages & Levels \\
\hline Nursery school & $(2) 3-6$ & ISCED 020 \\
\hline
\end{tabular}

Primary and Lower Secondary Education - The school attendance is compulsory for nine years, usually from the age of 6 to 15. The education is provided mainly by basic schools (základni škola). The compulsory school attendance starts at the beginning of the school year following the child's sixth birthday, unless he/ she is granted a postponement (OECD, 2016). Pupils start their compulsory school attendance in the nine-year basic school consisting of two stages which correspond to primary (grades 1-5) and lower secondary (grades 6-9) levels of education. Almost $13 \%$ of pupils leave a basic school at the end of the fifth year or the seventh year to enter multi-year general secondary schools (gymnázium). Small number of pupils start attending eight-year conservatoires (konzervator) after completing the fifth year of the basic school (OECD, 2016).

Table 2

Primary and Lower Secondary in Czech Repulic

\begin{tabular}{lll}
\hline Institution & Ages & Achieved Levels \\
\hline Basic school & & \\
- first stage & $6-10$ & ISCED 100 \\
- second stage & $11-15$ & ISCED 244, EQF 1 \\
$\begin{array}{l}\text { Multi-year general } \\
\text { (lower stage) }\end{array}$ & $11 / 13-15$ & ISCED 244, EQF 1 \\
Eight-year conservatoire (first 4 years) & $11-15$ & ISCED 244, EQF 1 \\
\hline
\end{tabular}

\section{Part (2): New Recent Developments in ICT in the European Primary education}

In most of the Eastern European countries, ICT is viewed as a separate subject. In Norway, Sweden and Ireland it is considered as a tool for use across the curriculum, whereas more typically in central European Member States (plus Iceland, Finland and Latvia) it is both a subject and a tool. In Portugal, Cyprus and Italy it is not formally taught. In Finland, decisions are made at local level and the treatment of ICT may, therefore, differ widely. There will also be disparities within other countries despite the existence of national curricula or guidelines. In this part, the researcher will survey on new recent developments in various European countries in the European Primary education, focusing primarily on the topics of uptake of ICT in primary education, the concept of digitization in primary schools, and the application of ICT for student assessment.

\subsection{Recent Findings on the Uptake of ICT in Education in European Countries}

An essential metric for the incorporation of computers into European primary schools has been the relationship between the number of students and availability of computers, aggregated at the national level. This metric is reported in, among other studies, the IEA studies SITES Module 1 (Pelgrum \& Anderson, 1999), SITES 2006 (Law et al. 2008), and ICILS 2013 (Fraillon et al. 2014), as well as in the OECD PISA studies from 2006 and onward (OECD 2006, 2010b, 2014a, 2016b). According to the latest PISA 2015 results (OECD 2016b), the median number of computers accessible per student aggregated at the country level is 0.66 for the 40 European educational systems participating in the study, ranging from 0.14 in Kosovo to 1.49 in Iceland. In comparison to other countries, a median of $97.8 \%$ of computers are connected to the Internet, again with huge variations, ranging from 29.2\% in Kosovo to $100 \%$ in Malta. The results from IEATIMSS 2015 (Mullis et al., 2016) demonstrated that, of the 11 participating European countries that reported on the availability of computers for mathematics lessons in grade 8 , the average coverage was $32 \%$ of students, ranging from $4 \%$ in Malta to $65 \%$ in Sweden. For grade 4, the average coverage among the 23 participating European countries was $40 \%$, ranging from $13 \%$ in Serbia to $84 \%$ in Denmark.

Digitization of Schools and BYOD Initiatives - A wide range of principles can be used to describe the

4 Consortia Academia Publishing (A partner of Network of Professional Researchers and Educators) 
digitization of schools. According to a report from the European Schoolnet based on a survey of school IT administrators in Europe, countries vary widely according to their levels of digitization. The report states that six countries can be grouped together with respect to the extent of digitization: Highly digitized schools Denmark, Norway, and Sweden. Digitally developing schools Poland, Romania, and Turkey. Moreover, there are two Linux countries, Italy and Spain, with high levels of equipment and above-average Linux OS penetration (European Schoolnet 2015b, p. 24). Educational authorities and school owners are increasingly supporting one-to-one learning environments for their students and teachers in primary schools. Because of considerable costs, a growing interest in BYOD (bring your own device) or BYOT (bring your own technology) approaches rises. Such approaches to meet greater access needs also improve demands on teachers, who need to be ready to assist their students with a range of different digital tools (European Schoolnet, 2015c). An example of BYOD implementation can be found in Austria, where two national initiatives are helping to drive e-Learning, mobile learning, and BYOD (European Schoolnet 2015c).

Assessment and Digital Exams - Assessment practices influence and guide student learning in many different ways. Efforts to digitalize matriculation exams are on the agenda in several European countries. Such interventions can have strong and significant effects on digitalization and the overall implementation of ICT in primary schools. For example; In Finland, the Finnish National Matriculation Examination Board is digitalizing the matriculation examination via the digitalization project DigiAbi (2016-2019). This project "digitalization project DigiAbi" will allow Finnish students to use the most common office applications, including multimodal text (such as text, pictures, audio, and video), to respond to questions in the matriculation exam. Of all European countries, Denmark is likely the most advanced in terms of online exams in upper secondary schools. In 2013, Denmark adjusted the Strategy for Digital Welfare, including an initiative for digital written tests in upper secondary education. The initiative also includes digital support for giving marks on academically relevant assignments and tests in primary and secondary schools (European Schoolnet 2015d).

\subsection{New Trends of Technology of Primary Schools in Europe and Czech Republic}

Nowadays, with the advent of World-Wide Web and internet, technology play a vital role in primary education particularly (Rahman Hakim \& Kodriyah, 2015). The degree of combination of technology in-class is directly correlated with the teacher's enthusiasm to use the technology in their lessons (Camilleri \& Camilleri, 2017a). In this respect, using technologies to play game helps students apply their conceptual knowledge. That is why existing studies have showed that using technologies in the education process can develop students' learning interests (Ebner \& Holzinger, 2007). Primary school students also have the ability to use technology in order to solve problems through creating and using strategies (Bottino et al., 2007). Using technology in teaching creates various types of stimuli included in activity oriented learning. Learning material is more interesting using technology and technology also increases media literacy of students and teachers (Naga Subramani, \& Iyappan, 2018). In addition, technology is changing the classroom experience as well. Information Communication Technology (ICT) has made many innovations and developments in teaching. ICT has also made an extreme change in the old pattern of teaching and learning. It is reported that student's role is more important than teachers in the new pattern of learning (Vijayalakshmi, Phil, \& Phil, 2019).

Teachers' insights regarding ICT can affect to limit or improve the application of technology in primary education. It is reported that the primary school teachers should be well-informed about the educational goals of the ICT tools. They can apply specific technologies in particular lessons so that the teachers are able to support important combination (Camilleri \& Camilleri, 2020). There are some innovative trends in primary education in Europe and Czech Republic. To this end, 5 newest educational trends including Artificial Intelligence, Edmodo, Kahoot, Flipped Classroom Learning, and Mobile Learning.

\subsection{ICT in Czech Republic}

The Czech Republic has devised a strategy for educational policies for the period from 2014 to 2020. The 
strategy has three important priorities: to reduce inequality in education, to endorse quality teacher training, and to support the responsible and efficient management of the educational system. The strategy can connect and link to ICT in primary schools through a general recognition of the significance of the role of digital technologies in teaching and learning. The initiative also includes a separate strategy for digital education, with a strong emphasis on modernizing the Czech educational system and making students become lifelong learners in a digital society and a digitized labor market. The digital education strategy has three priority objectives for interventions: new digital teaching and learning methods, students'school-related digital competences, and the growth of computational thinking. Concrete initiatives are operational programs emphasizing on the purchase of ICT equipment and teacher training in the field of ICT (European Schoolnet, 2015g).

\section{Part (3): Teaching Methods in Primary Schools (Europe vs Czech Republic)}

According to Maňák and Švec (2003), a teaching method shows "a dynamic element" in teaching and pedagogy, which changes relatively rapidly and adapt to new circumstances, objectives, and goals in comparrison with the content and organizational forms. The teaching methods are not the decisive determinant of teaching, but only one of the elements of the educational system, and therefore cannot replace the missing content and compensate the indistinct target. On the contrary, they are tied to the overall concept of teaching and only within it are they fully functional and effective.

Many other authors such as Harmer (1998), Storch (1999) or Scrivener (2005) talk about teaching methods in the same way, according to whom a teaching method is a teaching specifically didactic activity of the subject and object of teaching, improving the educational profile of a student, wherease acting educationally, in terms of training and educational objectives and in accordance with teaching and educational principles. It lies in the modification of content, directing the activity of subject and object, organisation of the sources of knowledge, techniques and procedures, ensuring fixation or control of knowledge and skills, cognitive attitudes, interests and processes (Skutil, Hvalíčková, and Matějíčková, 2014).

The ideal subject, where it is possible to make full use of both classic and modern material resources, is the teaching of National History and Geography. The content of this subject is based on the Framework Education Programme for Basic Education (Framework Educational Programme for Elementary Education, 2007), namely the educational area of Humans and the world, while this area consists of topics like The Place Where We Live, People around Us and People and Time. National History and Geography include geographic and historical curriculums. The geographical curriculum follows on the knowledge of natural science. Pupils move their observations from the closest area of residence and school to geographic observations of their region, the Czech Republic and Europe. They learn about neighboring countries, their natural conditions, economic and social advancement. They search important European cities and tourist centers on maps and acquire basic knowledge of the process of European unification. In the historiographical curriculum, pupils learn about significant personalities and historical stages of our national history, they learn to classify the main events into centuries, they acquire basic historiographical concepts associated with the organization of society (Skutil, Hvalíčková, and Matějíčková, 2014).

\section{Part (4): Curriculum Education System}

The curriculum varies greatly in each European country. There are two stages of curriculum education system including Primary and lower secondary education (NCEE, 2006). The curriculum of the stage of Primary education consistutes nine subjects including Czech language and literature, introduction to acquiring knowledge, the principles of geography and geology, the principles of natural sciences, mathematics, physical education, musical education, work education, and drawing, painting and sculpture (NCEE, 2006).

The curriculum for the stage of lower secondary education (6 to 9 years) consists of foreign language, civic education, history, biology, physics, and chemistry, as well as optional subjects including a second foreign 
language, computer science, or technical education (NCEE, 2006). Czech has given more freedom to regions and school head to decide what materials must be taught (Arvaz, 2020). The educational curriculums are: (1) Language and language communication, (2) Mathematics and its application, (3) ICT, (4) People and their world, (5) People and society, (6) People and nature, (7) Art and culture, (8) People and their health, (9) People and the world of work. The cross-curricular topics comprise: Personal and social education, Education for democratic citizenship, Education towards thinking in the European and global context, Multicultural education, Environmental education, and Media studies (OECD, 2020).

\section{Part (5): Evaluation and Assessment System}

\subsection{New Methods for Assessment}

There has been a recent innovation across the EU towards competence-based teaching and learning in primary schools (Gordon et al., 2009). Nowadays, school curricula pay remarkable attention to the growth of skills such as creativity, critical thinking, collaboration, or problem solving skills and important competencies which are considered as needed for global citizens and workers. However, in many EU countries, the assessment system has not changed and is still primarily emphasized on summative assessment of static knowledge and end-results, without attention on the learning process and the acquisition of competences and skills. Although there are alternative assessment methods -more process and formative orientated such as portfolios or rubrics-, they are not widespread and they are often seen as additional activities rather than an integral part of the curriculum.

Also, ICT technologies enable alternative assessment forms, also called e-assessment (JISC, 2007). A number of e-assessment tools are already available, and have proved their usefulness to meet assessment needs and improve learning. However, teachers, especially in primary education, have not adopted them yet. Therefore, there is a need to change the current practices and to support teachers with integrating modern assessment approaches and tools for learning as part of the curriculum.

e-Portfolio - They are an electronic version of traditional portfolios, which means that the work samples inside them will be of digital nature; coming from various sources and instruments (Subrahmanyam et al., 2012). The $\boldsymbol{e}$-Portfolio facilitates the capabilities of the learning portfolio to indicate the process and results of a learning path, proving the quality and level of achievement of the targeted competences (Butler, 2006). The ePortfolio should include basic storing capabilities, with interoperability support, as well the management of permissions and mechanisms to provide feedback on the shared artefacts. Finally, various views of the work samples should be possible, in order to highlight the competences of interest in each case.

Learning Analytics (LA) can be viewed as the measurement, collection, analysis, and reporting of data about learners and their contexts, for purposes of understanding and optimizing learning and the environments in which it occurs (Siemens \& Baker, 2016). LA permits primry students who are responsible for the teaching and learning process to identify possible learning risks, and make the necessary changes, depending on the situations encountered. Many LA systems and approaches are being developed, like the ones based on Social Network Analysis. In spite of the recent interest in these techniques, still a major challenge is to adapt the output and visualizations to the teacher's and learner's needs.

Enriched Rubrics - Learning analytics can be combined with rubrics in the so-called enriched rubrics (Petropoulou et al., 2012). These instruments are in the form of traditional rubric, but (at least part of) the criteria is assessed by indicators automatically computed from the interaction of the students with the system. They have been tested combined with the analytical capabilities provided by learning management systems, such as Moodle learning.

\subsection{Assessment System in Czech Republic}


In the Czech education system, student assessment has traditionally been the exclusive responsibility of teachers (Strakova \& Simonova, 2013). The country has regularly participated in international surveys, but the findings from these only started to influence educational policy during the past decade, when Czech students' performance fell markedly in all assessment domains (Strakova \& Simonova, 2013). The principal response has been to introduce standardized school-leaving examinations at different points in the primary school systems. The examinations have several widely acknowledged shortcomings, however, and in the meantime assessment for learning remains a neglected area. The improvement of evaluation and assessment practices in the Czech Republic is hindered by low levels of expertise among teachers, principals and policy-makers, and the private sector testing agencies that have become very active in the country suffer from the same weaknesses (Strakova \& Simonova, 2013). According to OECD (2020), evaluation and assessment system constitutes administering standardized national examinations, tests and sampled assessments to offer system-level data on student learning results. It is reported that external school assessments are considered as the important responsibility mechanism within the education system and ČŠI must assess each school every six years (OECD, 2020). In addition, it is necessary that schools perform internal self-evaluations and determine their conditions, structure and content. Therefore, schools are also required to publish annual activity reports (OECD, 2020). A significant test was introduced which is considered as general study prerequisites. It assesses verbal, mental and quantitative reasoning of students (Dvořák, et al., 2014). This test is used by schools for admission purposes and helps them not only assess students' proctographic knowledge, but also identify their potentials for future success. In addition to being employed assessment at primary and secondary schools, it is used as a part of the admission process in more than 40 universities in Czech Republic at present (Dvořák, et al., 2014).

\section{Part (6): Parent Participation in Primary Education}

The participation of parents in their children's education or primary education has policy implications in every European country. As we know, parents have strong feelings about their children's schools and are becoming widely demanding and critical consumers in the field of primary school education. Parents can also make an effective contribution to school improvement via supporting school management and teachers, or they can impede progressing and establishing conflict. There are a number of ways, at both national and local level, where the participation of parents may have a strong effect on the quality of children's education. Parental participation may, for example, take place via:

$>\quad$ Statutory advisory and decision-making bodies (e.g., school boards).

$>$ Evaluation of their schools.

$>\quad$ Voluntary associations (e.g., parent associations).

$>$ Voluntary involvement in after-school activities and clubs.

$>\quad$ Voluntary involvement in classroom activities (e.g., paired reading).

$>$ Communications with the school and support of their children's learning and progress.

There are a number of areas where parents may participate. The review's Eurydice shows one remarkable dimensions of parental involvement, namely in the preparation of the school development plan. The data shows that in five European countries parents have decision-making powers in relation to the preparation of the school development plan. This is generally through a representative body such as a council or board. It is more common (18 European countries) for parents to have a consultative or advisory function. In some countries, for example the Netherlands, the council ratifies the plan improved by the authority. In four European countries, parents have no powers in terms of development planning although in each of these four countries they do have powers in other areas including school rules, control or allocation of expenditure. Finland represents an exception because the powers of councils vary so much between municipalities and the most recent legislation (1 January

8 Consortia Academia Publishing (A partner of Network of Professional Researchers and Educators) 
1999) does not contain provisions for parental consultation in its school system.

\subsection{The Role of Teachers and Primary Schools in supporting parental involvement}

Parents' communication with primary schools and parental involvement are also affected by school characteristics (Feuerstein, 2001). Schools play a vital and significant role in specifying the level and nature of parental involvement. Critical factors include teachers' beliefs about parents' role in the classroom and their responsibility to provide involvement opportunities to parents. Schools can help parents become involved by offering a range of options for engagement. Supporting parental involvement requires knowledge by teachers on how to involve parents, and leadership and support from the school administration. Kerbow and Bernhardt (1993) noted that some schools seem to have more ability than others to promote parent involvement. Schools can help parents decide to be involved by offering a range of options for interactions that take parental needs into account. Invitations to parents to be involved convey to parents that their involvement is welcome and valued and provide motivation to be involved. Important invitations come from three sources: the school, teachers, and children themselves (Hoover-Dempsey et al., 2005). A school climate that conveys to parents that they are welcome in the school is essential. Parents can also be kept well-informed about their children's learning. The school staff can show respect for parental concerns and suggestions. Such a school climate sets a strong foundation for involvement. Invitations from the teacher build personal trust that is the basis for creating a partnership around children's learning at home and at school. Invitations from children for help with their learning can also prompt involvement. This is consistent with developmental research that children's behaviors can influence parents' socialization practices.

\subsection{Parent Participation in Czech Republic}

In the Czech Republic education system, parents play an important role in daily school life and children's educational progression (Rabusicová, \& Emmerová, 2002). According to the Family Act in the Czech Republic, the Act puts a crucial emphasis on the role of parents and their participation in children's education: 'Crucial role in the education of children is that of parents' (Act no. 94/1963 of the Code of Laws, on family, article 32, paragraph 1). This fact is indicated in the School Act as well: 'The legal representative of the child, foster-parent, citizen or an institution, that a child was consign to by a judicial verdict, is obliged to enrol a child at the school age in school and take care that the child goes to school regularly and on time; they are also obliged to make a declaration to the child's application for secondary-school studies. If they enrol the child in a club for afterschool activities, they are obliged to take care that the child goes there regularly and on time (Act no. 29/1984 of the Code of Laws, on the system of primary, secondary and higher vocational schools [the School Act], in the form of subsequent laws, article 36)' as cited in Rabusicová, and Emmerová, (p. 484, 2002).

The Czech schools have the commitment to work with parents to increase the children's progression and intensify the common educational impact of the family and the schools. Parents must also work with the schools when their child cannot attend the school due to illness, or in case their child is very talented, or parents distrust the fairness of classification (Ordinance no. 219/1991, on primary school, article 4, paragraph 2, paragraph 3, article 11, paragraph 3) (Rabusicová, \& Emmerová, 2002). It is worth noting that parent participations in the educational contexts in the Czech Republic indicate that the school needs parents to make decisions on their children. However, the Czech Republic does not provide the contextual situations for the creation and progression of the parent participation with the school (Rabusicová, \& Emmerová, 2002).

\section{Conclusion}

The present study aims to investigate the new trends of innovation of primary education in Europe and Czech. To this end, the researcher selected six main indicators on new trends of innovation of primary education

in Europe and Czech Republic as holistic approach. These 6 indicators include 1) Structure of Educational Systems, 2) New Recent Developments in ICT in the European Primary education, 3) Teaching Methods in 
Primary Schools (Europe vs Czech Republic), 4) Curriculum Education System, 5) Evaluation and Assessment, and 6) Parent Participation in Primary Education. It is worth noting that the researcher explains the educational context in Europe and Czech for each indicator which constitutes information about the educational context in Europe and Czech. With respect to the above-mentioned indicators, we can conclude important points in terms of each main indicators.

In Czech Republic, the education system is highly decentralized compared with other European countries. Czech's education governance is divided into several parts and some municipalities have low ability or sources which help inequalities. It is reported that the present policy of more equal distribution of finances across regions makes sure equity. In addition, the early childhood education and care can enhance the equity of education (OECD, 2020). In most of the Eastern European countries, ICT is considered as a separate subject. For example; in Norway, Sweden and Ireland ICT is viewed as a tool for use across the curriculum, whereas more typically in central European Member States (plus Iceland, Finland and Latvia) it is both a subject and a tool. And for other countries such as Portugal, Cyprus and Italy, ICT it is not formally taught.

In Finland, decisions are made at local level and the treatment of ICT may, therefore, differ widely. There will also be disparities within other countries despite the existence of national curricula or guidelines. Period from 2014 to 2020, the Czech Republic has devised three strategies for ICT. This strategy has three important priorities: 1) to reduce inequality in education, 2) to endorse quality teacher training, and 3) to support the responsible and efficient management of the educational system. With regard to the use of teaching methods in Europe and Czech Republic, we can find a significant difference only in comprehensive teaching methods, which represent the practices more emphasized on collective activities, which essentially corresponds to the findings of the organizational forms of teaching category. Significant differences were found in the use of modern technology in teaching. Here, the Czech Republic dominates quite significantly. Although Spanish schools have adequate equipment, it must be admitted that technologisation of schools in the Czech Republic is at a considerably high level, and the qualifications of teachers to work with ICT. Likewise, the motivation of teachers in the Czech Republic for the use of ICT in teaching is higher than those of teachers in Spain. This corresponds to the findings presented.

Based on Curriculum Education, the main discrepancy between European Countries and Czech Republic was concerned with the way the curricula for schools are developed. For instance, in Czech, schools have a high degree of autonomy to not only develop their own curriculum but to appoint and dismiss teachers. The objective of Early Childhood Education (ECE) curriculum is to support children's growth towards humanity and ethically responsible membership of society, and to provide children with the knowledge and skills necessary in life. In terms of the role of parents in primary education, the participation of parents in primary education has policy implications in every European country. As we know, parents have remarkable feelings towards their children's schools and are becoming widely demanding and critical consumers in the field of primary school education. There are a number of areas where parents may participate. The review's Eurydice shows one significant aspects of parental involvement, namely in the preparation of the school development plan. The data shows that in five European countries parents have decision-making powers in relation to the preparation of the school development plan. This is generally through a representative body such as a council or board. It is more common (18 European countries) for parents to have a consultative or advisory function.

In some countries, for example the Netherlands, the council ratifies the plan improved by the authority. In four European countries, parents have no powers in terms of development planning although in each of these four countries they do have powers in other areas including school rules, control or allocation of expenditure. Finland represents an exception because the powers of councils vary so much between municipalities and the most recent legislation (1 January 1999) does not contain provisions for parental consultation in its school system. Therefore, the present study demonstrated that European countries including the Czech Republic have various opinions towards the presentation of these indicators on the quality of school education. Moreover, using the afore-mentioned information of these indicators, European countries can look outwards so as to explore 
Trends of innovation of primary education in Europe

students' performance and achievement in comparison with their counterparts. The results of this study are also useful for policy makers, educators, students, parents and the public.

\section{References}

Arvaz, S. (2020). The Czech Republic and the Islamic Republic of Iran's primary and secondary educational systems: A comparative study. Retrieved from https://is.muni.cz/th/d641s/

Camilleri, M. A. \& Camilleri, A. C. (2020). The use of mobile learning technologies in primary education. In R. Zheng (Ed.), Cognitive and affective perspectives on immersive technology in education. IGI Global, Hershey, USA.

Camilleri, M. A., \& Camilleri, A. C. (2017). Digital learning resources and ubiquitous technologies in education. Technology Knowledge and Learning, 22(1), 65-82.

Dvořák, D., Urbánek, P., \& Starý, K. (2014). High autonomy and low accountability: Case study of five Czech schools. Pedagogická orientace, 24(6), 919-940.

Ebner, M., \& Holzinger, A. (2007). Successful implementation of user-centered game-based learning in higher education: An example from civil engineering, Computers \& Education, 49(3), 873-890.

European Commission. (2000). European report on the quality of school education. Sixteen Quality Indicators. Report based on the work of the working committee on quality indicators. Directorate-General for Education and Culture.

European Schoolnet. (2014). Computing our future: Computer programming and coding -Priorities, school curricula and initiatives across Europe. Brussels: European Schoolnet. Retrieved from http://www.eun.org/publications/detail?publicationID=481

European Schoolnet. (2015a). Computing our future: Computer programming and coding -Priorities, school curricula and initiatives across Europe (2015 update). Brussels: European Schoolnet. Retrieved from http://fcl.eun.org/documents/10180/14689/Computing+our+future_final.pdf/746e36b1-e1a6-4bf1-8105ea27c0d2bbe0

European Schoolnet. (2015b). The school IT administrator. Analyzing the profile, role and training needs of network administrators in Europe's schools. Brussels: European Schoolnet.

European Schoolnet. (2015c). BYOD -Bring your own device. A guide for school leaders. Brussels: European Schoolnet. Retrieved from http://fcl.eun.org/documents/10180/624810/BYODreport_Oct2015_final.pdf

European Schoolnet. (2015f). Belgium Flanders. Country report on ICT in education. Brussels: European Schoolnet. Retrieved from http://www.eun.org/c/document_library/get_file?uuid=1e6e0d6e-7d51-4dd3-a2a7-b8cd6a868100\&grou $\mathrm{pId}=43887$

European Schoolnet. (2015g). Czech Republic. Country report on ICT in education. Brussels: European Schoolnet. Retrieved from http://www.eun.org/c/document_library/get_file?uuid=968946f9-06d6-4423-b49f-1759af1d5768\&grou $\mathrm{pId}=43887$

Feuerstein, A. (2000). School characteristics and parent involvement: Influences on participation in children's schools. The Journal of Educational Research, 94(1), 29-39.

Fraillon, J., Ainley, J., Schulz, W., Friedman, T., \& Gebhardt, E. (2014). Preparing for life in a digital age. The IEA international computer and information literacy study. International report. Cham: Springer.

Framework Educational Programme for Elementary Education. Praha:VÚP, 2007.

Gordon, J., Halasz, G., Krawczyk, M., Leney, T., Michel, A., Pepper, D., et al.: (2009). Key competences in Europe: Opening doors for lifelong learners across the school curriculum and teacher education. Warsaw.

Harmer, J. (1998). How to teach English. England: Addison Wesley Longman Limited.

Hoover-Dempsey, K. V., Basssler, O. C., \& Brissie, J. S. (1992). Explorations in parentschoolrelations. Journal of Educational Research, 85(5), 287-294.

JISC. (2007). Effective practice with e-assessment. An overview of technologies, policies and practice in further and higher education. Bristol. 
Kerbow, D., \& Bernhardt, A. (1993). Parental involvement in the school: The context of minority involvement. In. B. Schneider \& J. Coleman (Eds.), Parents, their children, and schools (pp. 115-146). Boulder, CO: Westview.

Law, N., Pelgrum, W., \& Plomp, T. (Eds.). (2008). Pedagogy and ICT use in schools around the world: Findings from the IEA SITES 2006 study. CERC studies in comparative education. Dordrecht: Springer.

Maňák, J., \& Švec, V. (2003).Výukové metody [Teaching methods]. Brno: Paido,

Mullis, I. V. S., Martin, M. O., \& Loveless, T. (2016). 20 years of TIMSS: International trends in mathematics and science achievement, curriculum, and instruction. Chestnut Hill: TIMSS \& PIRLS International Study Center, Boston College. Retrieved from http://timss2015.org/timss2015/wp-content/uploads/2016/T15-20-years-of-TIMSS.pdf

NCEE. (2006). National Center on Education and the Economy New Commission on the Skills of the American Workforce Profile of the Czech Republic's Education System.

OECD. (2006). Are students ready for a technology-rich world? What PISA studies tell us. Paris: OECD Publishing. Retrieved from: http://www.oecd-ilibrary.org/education/are-students-readyfor-a-technology-rich-world_9789264036093 -en

OECD. (2010). PISA 2009 results: What students know and can do: Student performance in reading, mathematics and science (volume I). Paris: OECD Publishing.

OECD. (2016). School education in the Czech Republic. OECD Reviews of School Resources: Czech Republic.

OECD. (2020). Education Policy Outlook Czech Republic.

Pelgrum, W. J., \& Anderson, R. E. (1999). ICT and the emerging paradigm for life-long learning. Amsterdam: IEA.

Rabusicová, M., \& Emmerová, K. (2002). The role of parents as educational and social partners of schools in the Czech Republic: Legislation and media analysis. European Educational Research, 1(3).

Rahman Hakim, A., \& Kodriyah, L. (2015). Edmodo- an effective solution to blended learning for EFL Learners. Proceedings of the 1st National Conference on English Language Teaching (NACELT).

Scrivener, J. (2005). Learning Teaching. Oxford: Macmillan.

Siemens, G., \& Baker, R. (2012). Learning analytics and educational data mining: towards communication and collaboration. In Proceedings of the 2nd International Conference on Learning Analytics and Knowledge (LAK '12), Simon. Shum, B., Gasevic, D., \& Ferguson, R. (Eds.). ACM.

Skutil, M., Havlíčková, K., \& Matějíčková, R. (2014). Educational process in terms of teaching methods and organisational forms in small schools. New horizons in education - INTE 2014 conference proceedings. Sakarya: Sakarya Üniversitesi, 359-363.

Storch, D. (1999). Deutsch als Fremdsprache-Eine Didaktik. München: Wilhelm Fink Verlag.

Strakova, J., \& Simonová, J. (2013). Assessment in the school systems of the Czech Republic. Assessment in Education: Principles, Policy \& Practice, 20(4), 470-490.

Vijayalakshmi, M. (2019). Innovations in Teaching Methods. JASC: Journal of Applied Science and Computations, 6(1), 25-88. 